\begin{tabular}{l|l} 
Jurnal Eksplorasi Akuntansi & $\begin{array}{l}\text { ISSN : 2656-3649 (Online) } \\
\text { hol. 1, No 4, Seri B, November 2019, Hal 1773-1793 }\end{array}$
\end{tabular}

\title{
PENGARUH KEJELASAN SASARAN ANGGARAN, AKUNTANSI PERTANGGUNGJAWABAN, DAN LATAR BELAKANG PENDIDIKAN TERHADAP KINERJA MANAJERIAL DI SATUAN KERJA KEMENTERIAN PERINDUSTRIAN PADANG
}

\author{
Hayatul Hikmah Johan", Efrizal Syofyan ${ }^{2}$ \\ ${ }^{1}$ Alumni Jurusan Akuntansi Fakultas Ekonomi, Universitas Negeri Padang \\ ${ }^{2}$ Jurusan Akuntansi Fakultas Ekonomi, Universitas Negeri Padang \\ *Korespondensi: hayatulhikmah@yahoo.com
}

\begin{abstract}
Abstrack: This study aims to 1) The extent to which the clarity of budget targets influences the management performance in the Work Unit of the Ministry of Industry of Padang. 2) The extent to which responsibility accounting influences managerial performance in the Work Unit of the Ministry of Industry, Padang. 3) The extent to which educational background influences managerial performance in the Work Unit of the Ministry of Industry of Padang and 4) The extent to which clarity of budget targets, responsibility accounting and educational background influences simultaneously on managerial performance in the Work Unit of the Ministry of Industry of Padang. In this study the design of this study is the Design of Causality. The data used are 1) primary, which is the answer to be analyzed for statistical testing purposes, 2) Secondary data, i.e. data needed to support this study were obtained from primary data, ie data obtained directly from the Work Unit of the Ministry of Industry of Padang concerning clarity budget goals, accountability accounting, educational background and managerial performance. This means that together with the variables of the clarity of budget targets, accountability accounting and education affect managerial performance in the Work Unit of the Ministry of Industry, Padang.
\end{abstract}

Keywords: Clarity of Budget Goals; Responsibility Accounting; Educational Background and Managerial Performance

\section{How to cite}

Johan, H.H. \& Syofyan, Efrizal, (2019). Pengaruh Kejelasan Sasaran Anggaran, Akuntansi Pertanggungjawaban dan Latar Belakang Pendidikan terhadap Kinerja Manajerial Di Satuan Kerja Kementerian Perindustrian Padang. Jurnal Eksplorasi Akuntansi, 1(4), Seri B, 1773-1793.

\section{PENDAHULUAN}

Kinerja sektor publik sebagian besar dipengaruhi oleh kinerja aparat atau manajerial. Wilson (2012) menyatakan bahwa kinerja (performance) merupakan kuantitas dan kualitas pekerjaan yang diselesaikan oleh individu, kelompok atau organisasi. Menurut Mahoney et. al. (1963) dalam Natalia (2010) kinerja manajerial adalah kinerja para individu anggota organisasi dalam kegiatan manajerial, antara lain perencanaan, investigasi, pengkoordinasian, evaluasi, pengawasan, pengaturan staf, negoisasi, perwakilan dan kinerja secara keseluruhan. Kinerja manajerial menunjukkan kemampuan dan prestasi seorang manajer dalam menjalankan 
organisasi untuk mewujudkan tujuan yang mengarah kepada ketercapaian pelayanan publik. Kepentingan kinerja manajerial dibutuhkan untuk menilai seberapa jauh lembaga atau organisasi dapat menerapkan visi, misinya agar pelayanan publik dapat terwujud.

Hal yang berkaitan dengan kinerja manajerial adalah kejelasan sasaran anggaran, akuntansi pertanggung jawaban, dan latar belakang pendidikan. Dengan adanya kejelasan sasaran akan berkontribusi terhadap kinerja anggaran karena kinerja anggaran akan tergambar dari kejelasan sasaran anggaran dan penggunaannya (Suhartono 2016). Hasil penelitian terdahulu Efrizar (2017) menujukkan adanya pengaruh kejelasan sasaran anggaran, akuntanbilitas publik, dan sistem pelaporan terhadap kinerja manajerial. Penelitian ini sejalan dengan Hidayattullah (2017) yaitu adanya pengaruh kejelasan sasaran anggaran, pengendalian akuntansi, sistem pelaporan terhadap akuntabilitas kinerja SKPD di Merauke.

Akuntansi pertanggungjawaban adalah suatu sistem akuntansi yang disusun sedemikian rupa sehingga pengumpulan dan pelaporan biaya dan pendapatan dilakukan sesuai dengan pusat pertanggungjawaban dalam organisasi dengan tujuan agar dapat ditunjuk orang atau kelompok orang yang bertanggungjawab atas penyimpangan biaya dan pendapatan yang dianggarkan (Mulyadi, 2014). Akuntansi pertanggungjawaban juga disebut suatu bentuk laporan keuangan yang digunakan untuk mengevaluasi kinerja keuangan perusahaan atau instansi pemeritahan. Manajemen yang bertanggung jawab atas segala perencanaan, pencapaian sasaran pelaksanaan, dan hasil pelaporan pertanggungjawaban dituangkan kedalam akuntansi pertangungjawaban. Hasil penelitian terdahulu Kinasih (2010) menunjukkan adanya pengaruh penerapan akuntansi pertanggungjawaban terhadap kinerja manajerial dengan motivasi sebagai variabel intervening.

Latar belakang pendidikannya yang dimiliki oleh seseorang memberikan kontribusi terhadap kualitas maupun kuantitas kerja seseorang. Pendidikan memberikan pengetahuan kepada seseorang dalam menyelesaikan pekerjaannya, dengan latar belakang pendidikan maka memberikan pengetahuan kepada pegawai agar bekerja lebih baik. Fenomena yang terjadi pada saat ini pada kinerja manajerial adalah kurangnya tenaga yang terampil dan ahli dibidangnya pegawai yang ditempatkan pada bagian anggaran adalah yang memiliki latar belakang pendidikan yang tidak sesuai dengan bidang kerjanya, hal ini menghambat kinerja karena mereka bekerja berdasarkan pengalaman namun tidak berdasarkan latar belakang pendidikannya.

Survei awal melalui wawancara yang dilakukan terhadap 10 orang pegawai bagian pengelola anggaran pada bulan Februari 2019 ditemukan permasalah 8 orang pegawai $(80 \%)$ kurang memahami mengenai perencanaan, investigasi, koordinasi dan evaluasi dalam penyusunan anggaran, 4 orang (40\%) terkadang tidak mengerti tujuan anggaran, 5 orang (50\%) dalam penyusunan anggaran belum memahami kejelasan dari sasaran anggaran, dan 7 orang (70\%) pegawai memiliki latar belakang pendidikan yang bukan dari jurusan akuntansi. Data lain yang peneliti peroleh di lapangan berkenaan dengan pendidikan memiliki latar belakang yang berbeda.

Penelitian ini dilaksanakan pada Satuan Kerja Kementerian Perindustrian Padang, alasan peneliti melakukan penelitian disini karena berdasarkan survei awal terjadinya permasalahan berkenaan dengan kinerja manajerial. Berdasarkan pemikiran dan penjelasan diatas maka penulis tertarik untuk melakukan penelitian dengan judul "Pengaruh Kejelasan Sasaran Anggaran, Akuntansi Pertanggungjawaban dan Latar Belakang Pendidikan Terhadap Kinerja Manajerial Di Satuan Kerja Kementerian Perindustrian Padang". 


\section{REVIEW LITERATUR DAN HIPOTESIS \\ Teori Keagenan (Agency Theory)}

Teori yang mendasari penulisan ini adalah teori agensi. Menurut Jensen dan Meckling (1976) dalam Ujiyantho (2007), menyatakan bahwa hubungan keagenan merupakan sebuah kontrak antara manajer atau pemerintah (agent) dengan investor atau rakyat (principal). Konflik kepentingan antara pemilik dan agen terjadi karena agen tidak selalu berbuat sesuai dengan kepentingan principal. Untuk mengawasi perilaku pemerintah serta menyelaraskan tujuan rakyat dan pemerintah, rakyat mewajibkan pemerintah untuk mempertanggungjawabkan pengelolaan sumber daya yang dipercayakan kepada pemerintah melalui mekanisme pelaporan keuangan secara periodik. Melalui laporan keuangan yang merupakan tanggungjawab pemerintah, rakyat melalui legislatif dapat mengukur, menilai sekaligus mengawasi kinerja pemerintah, sejauh mana pemerintah telah bertindak untuk meningkatkan kesejahteraan rakyat.

\section{Prospect Theory}

Berdasarkan Prospect theory yang telah dikembangkan oleh Kahnerman dan Tversky (1979) memungkinkan seseorang untuk membuat pilihan dalam situasi di mana mereka harus memutuskan antara alternatif yang melibatkan risiko, misalnya dalam keputusan keuangan. Seseorang akan memutuskan untuk mendukung dan berperan aktif dengan mempertimbangkan hasil yang akan diperoleh sebagai kerugian atau keuntungan yang lebih besar.

\section{Pengertian Kinerja Manajerial}

Kinerja merupakan suatu prestasi atau tingkat keberhasilan yang dicapai oleh individu atau suatu organisasi dalam melaksanakan pada suatu periode tertentu. Wilson (2012) menyatakan bahwa kinerja (performance) merupakan kuantitas dan kualitas pekerjaan yang diselesaikan oleh individu, kelompok atau organisasi. Pada sektor pemerintahan, kinerja dapat diartikan sebagai suatu prestasi yang dicapai oleh pegawai pemerintah atau instansi pemerintah dalam melaksanakan pelayanan kepada masyarakat dalam suatu periode.

Kinerja manajerial merupakan kinerja para individu dalam kegiatan-kegiatan manajerial, seperti: perencanaan, investigasi, koordinasi, evaluasi, pengawasan, pengaturan staf, negosiasi dan perwakilan (Mahoney, 2013). Kinerja sebagai hasil kerja yang dapat dicapai oleh seseorang atau sekolompok orang dalam suatu organisasi sesuai dengan wewenang dan tanggung jawab masing-masing dalam upaya mencapai tujuan organisasi yang bersangkutan secara legal, tidak melanggar hukum dan sesuai dengan moral dan etika (Prawirosentono, 2013).

Kinerja merupakan faktor penting yang digunakan untuk mengukur efektitas dan efisiensi organisasi. Supomo dan Indriantoro (2011) menyatakan bahwa: Kinerja manajerial adalah kinerja para individu anggota organisasi dalam kegiatan-kegiatan manajerial, antara lain: perencanaan, koordinasi, supervisi, staffing, negosiasi, dan representasi. Bagi organisasi itu sendiri kinerja manajerial dapat menjadi tolak ukur sejauh mana manajer melaksakanan fungsi. Berdasarkan defenisi di atas dapat disimpulkan kinerja merupakan sebuah indikator dalam mengukur kualitas dan kuantitas kerja seseorang. Pada sektor pemerintahan, kinerja dapat diartikan sebagai suatu prestasi yang dicapai oleh pegawai pemerintah atau instansi pemerintah dalam melaksanakan pelayanan kepada masyarakat dalam suatu periode.

\section{Penilaian Kinerja Manajerial}

Perlu diingat bahwa penilaian kinerja adalah untuk memotivasi personel dalam mencapai tujuan organisasi. Dalam organisasi pemerintah, pengukuran kinerja pimpinan dilakukan untuk menilai 
seberapa baik melakukan tugas pokok dan fungsi yang dilimpahkan kepadanya selama periode tertentu (Indriantoro, 2011). Pengukuran kinerja pimpinan merupakan wujud dari pertanggungjawaban baik secara vertical accountability yaitu pengevaluasian kinerja bawahan oleh atasan dan sebagai bahan pertanggungjawaban secara horizontal pemerintah kepada masyarakat atas amanah yang diberikan kepadanya. Mahoney (2013) menyebutkan bahwa ada lima manfaat pengukuran atau penilaian kinerja suatu entitas pemerintahan yaitu:

1. Peningkatan kinerja meningkatkan mutu pengambilan keputusan. Seringkali keputusan yang diambil pemerintah dilakukan dalam keterbatasan data dan berbagai pertimbangan politik serta tekanan dari pihak-pihak yang berkepentingan. Proses pengembangan pengukuran kinerja ini akan memungkinkan pemerintah untuk menentukan misi dan menetapkan tujuan pencapaian hasil tertentu.

2. Pengukuran kinerja meningkatkan akuntabilitas internal. Lini teratas pun kemudian akan bertanggungjawab kepada pihak legislatif.

3. Pengukuran kinerja meningkatkan akuntabilitas publik. Keterlibatan masyarakat terhadap pengambilan kebijakan pemerintah menjadi semakin besar dan kualitas hasil suatu program juga semakin diperhatikan.

4. Masyarakat semakin kritis untuk menilai program-program pokok pemerintah sehubungan dengan meningkatnya pajak yang dikenakan kepada mereka. Evaluasi yang dilakukan cenderung mengarah kepada penilaian apakah pemerintah memang dapat memberikan pelayanan yang terbaik kepada masyarakat.

\section{Faktor-Faktor yang Mempengaruhi Kinerja Manajerial}

Ada beberapa faktor yang dapat mempengaruhi kinerja manajerial antara lain (Abdul, 2011) :

1. Faktor Pribadi (keahlian, pendidikan, kepercayaan diri, motivasi dan komitmen).

2. Faktor Kepemimpinan (kualitas keberanian atau semangat, pedoman pemberian semangat pada manajer dan pemimpin kelompok organisasi).

3. Faktor Tim atau kelompok (sistem pekerjaan, kejelasan sasaran anggaran, akuntansi pertanggungjawaban dan fasilitas yang disediakan oleh organisasi).

4. Faktor Situasional (perubahan dan tekanan dari lingkungan internal dan eksternal).

\section{Indikator Kinerja Manajerial}

Menurut Mahoney (2013), mengukur kinerja manajerial dengan melihat dari indikator :

1. Perencanaan, yaitu tindakan yang dibuat berdasarkan fakta dan asumsi yang akan datang guna mencapai tujuan yang diinginkan.

2. Investigasi, yaitu upaya yang dilakukan untuk mengumpulkan dan mempersiapkan informasi dalam bentuk laporan catatan dan analisa pekerjaan untuk dapat mengukur hasil pelaksanaannya.

3. Koordinasi, menyelaraskan tindakan yang meliputi pertukaran informasi dengan orang-orang dalam unit organisasi lainnya, guna dapat berhubungan dan menyesuaikan program yang akan dijalankan.

4. Evaluasi, yaitu penilaian atas usulan atau kinerja yang diamati dan dilaporkan.

5. Supervisi, yaitu mengarahkan, memimpin dan mengembangkan potensi bawahan serta melatih dan menjelaskan aturan-aturan kerja kepada bawahan.

6. Staffing, yaitu memelihara dan mempertahankan bawahan dalam suatu unit kerja, menyeleksi pekerjaan baru menempatkan dan mempromosikan pekerjaan tersebut dalam unit lainnya. 
7. Negosiasi, yaitu usaha untuk memperoleh kesepakatan dalam hal pembelian, penjualan atau kontrak untuk barang-barang dan jasa.

8. Representasi, yaitu menyampaikan informasi tentang visi, misi dan kegiatan-kegiatan organisasi dengan menghadiri pertemuan kelompok bisnis dan konsultasi dengan perusahaanperusahaan lain.

\section{Pengertian Kejelasan Sasaran Anggaran}

Anggaran dapat menumbuhkan partisipasi dan motivasi para manajer dalam mencapai tujuan yang telah ditetapkan maka semua tingkatan manajemen dari semua bagian harus dilibatkan dalam penyusunan anggaran. Anggaran yang realistis akan meningkatkan koordinasi antar individu, terlaksananya kebijakan manajemen, dan tercapainya tujuan yang telah diterapkan (Badric Siregar et.al, 2013).

Halim (2013), bahwa anggaran yaitu rencana kegiatan yang diwujudkan dalam bentuk finansial, meliputi usulan pengeluaran yang diperkirakan untuk suatu periode waktu, serta usulan cara-cara memenuhi pengeluaran tersebut. Anggaran adalah ekspresi kuantitatif suatu rencana yang dinyatakan dalam satuan fisik atau kekurangan atau keduanya (Bambang, 2013). Anggaran merupakan suatu perancanaan atau estimasi kinerja yang akan dicapai dalam jangka pendek yang merupakan penjabaran dari tujuan organisasi dengan mengalokasikan sejumlah sumber daya organisasi yang dimiliki untuk memenuhi kebutuhan pelaksanaan kegiatan-kegiatan organisasi. Dari pengertian di atas, maka dapat disimpulkan bahwa anggaran merupakan suatu rencana manajemen secara tertulis mengenai kegiatan suatu organisasi dan pada umumnya dinyatakan dalam satuan barang atau jasa untuk jangka waktu tertentu demi tecapainya tujuan yang telah ditetapkan (Damastu, 2017).

Dari beberapa pengertian diatas maka dapat disimpulkan bahwa anggaran dapat diartikan sebagai suatu rencana kegiatan suatu perusahaan yang disusun untuk masa depan perusahaan agar bisa berjala dengan efektif dan efisien. Nadirsyah, dkk (2012) menjelaskan bahwa kejelasan sasaran anggaran merupakan gambaran sejauh mana tujuan anggaran ditetapkan secara jelas dan spesifik dengan tujuan agar anggaran tersebut dapat dimengerti oleh pegawai yang bertanggung jawab atas pencapaian sasaran anggaran tersebut. Oleh karena itu sasaran anggaran pemerintah harus dinyatakan secara jelas, spesifik dan dapat dimengerti oleh mereka yang bertanggung jawab melaksanakannya. Hal ini akan mendorong karyawan atau staf untuk melakukan yang terbaik bagi pencapaian tujuan yang dihendaki sehingga berimplikasi pada peningkatan kinerja (Mulyadi, 2014).

Karakteristik anggaran adalah kejelasan sasaran anggaran. Selanjutnya, target-target anggaran yang disusun akan sesuai dengan anggaran yang ingin dicapai organisasi. Ketidakjelasan sasaran anggaran akan menyebabkan pelaksanaan anggaran menjadi bingung, tidak puas dalam bekerja. Hal ini menyebabkan pelaksana anggaran tidak termotivasi untuk mencapai kinerja yang diharapkan.

Berdasarkan defisini di atas dapat disimpulkan kejelasan sasaran anggaran akan membantu pegawai untuk mencapai kinerja yang diharapkan, dimana dengan mengetahui sasaran anggaran tingkat kinerja dapat tercapai. Keterlibatan individu akan memahami sasaran yang akan dicapai oleh anggaran tersebut. Serta bagaimana akan mencapainya dengan menggunakan sumber yang ada, selanjutnya target-target anggaran yang disusun akan sesuai dengan yang akan dicapai. Kejelasan sasaran anggaran juga merupakan sejauhmana tujuan anggaran ditetapkan secara jelas dan spesifik dengan tujuan agar anggaran tersebut dapat dimengerti oleh orang yang bertanggungjawab atas pencapaian sasaran tersebut. 


\section{Karakteristik Kejelasan Sasaran Anggaran}

Karakteristik anggaran adalah kejelasan sasaran anggaran. Selanjutnya, target-target anggaran yang disusun akan sesuai dengan anggaran yang ingin dicapai organisasi. Stteers dan Porter (1976) dalam Mulyadi (2014), bahwa dalam menentukan sasaran anggaran mempunyai karakteristik utama yaitu:

a. Sasaran harus spesifik bukannya samar-samar.

b. Sasaran harus menantang namun dapat dicapai.

\section{Keuntungan Kejelasan Sasaran Anggaran}

Bedric (2013) menyatakan bahwa keuntungan kejelasan sasaran anggaran adalah sebagai berikut:

1. Meningkatnya produktivitas dan perbaikan kualitas kerja. Kejelasan sasaran anggaran akan memberikan motivasi untuk meningkatkan produktivitas kerja.

2. Membantu menjelaskan apa-apa yang diharapkan. Sasaran anggaran yang jelas akan memberikan gambaran yang akan dicapai.

3. Menghilangkan kejenuhan.

4. Meningkatkan kepuasan terhadap hasil kerja yang dicapai.

5. Mempengaruhi tingkat persaingan pekerja secara spontan yang mana lebih lanjut akan meningkatkan kinerja mereka. Setiap pekerja akan termotivasi untuk bersaing secara sportif untuk bekerja sebab mereka dapat memahami arah perusahaan dengan mengetahui sasaran yang jelas.

6. Meningkatkan rasa kepercayaan diri dan rasa bangga jika sasaran tercapai dan akan menerima tantangan lebih lanjut.

7. Membangkitkan rasa mampu dalam bekerja sehingga akan meningkatkan kinerja. Sasaran yang jelas akan mampu membangkitkan motivasi kerja yang pada gilirannya akan meningkatkan kinerja para pekerja.

\section{Indikator Kejelasan Sasaran Anggaran}

Locke dan Lathan (1984) dalam Samuel (2014), menyatakan bahwa dalam pengukuran kejelasan sasaran anggaran ada enam indikator yang diperlukan:

1. Tujuan, membuat secara terperinci umum tugas-tugas yang harus dikerjakan.

2. Kinerja, menyatakan kinerja dalam bentuk pernyataan yang dapat diukur.

3. Standar, menetapkan standar atau target yang dicapai.

4. Jangka waktu, menetapkan jangka waktu yang dibutuhkan untuk pengerjaan.

5. Sasaran prioritas, menetapkan sasaran berdasarkan tingkat kesulitan dan pentingnya.

6. Koordinasi, menetapkan kebutuhan koordinasi.

Menurut Kenis dalam Rusdianto (2013) indikator yang digunakan dalam mengukur kejelasan sasaran anggaran adalah:

1. Jelas, artinya sasaran anggaran yang ingin dicapai harus diuraikan secara jelas serta tidak bermakna ganda (ambigu).

2. Spesifik, artinya sasaran anggaran yang ingin dicapai harus diuraikan secara spesifik dan detail, agar tidak menimbulkan interpretasi yang bermacam-macam.

3. Mengerti, artinya sasaran anggaran yang ingin dicapai mudah dimengerti serta menjadi prioritas utama. 


\section{Pengertian Akuntansi Pertanggungjawaban}

Pengertian akuntansi pertanggugjawaban menurut Anthony \& Govindarajan (2014) Akuntansi pertanggungjawaban bagian dari sistem pengontrolan akunting yang merupakan salah-satu faktor yang mendukung implementasi strategi, sedangkan strategi itu sendiri merupakan rencana pencapaian tujuan organisasi. Pada intinya, akuntansi pertanggungjawaban mensyaratkan setiap manajer untuk berpartisipasi dalam penyusunan rencana-rencana finansial segmennya dan menyediakan laporan kinerja tepat waktu yang membandingkan hasil aktual dengan yang direncanakan. Berdasarkan definisi di atas maka da[at disimpulkan akuntansi pertanggungjawaban yaitu bagaimana seorang pegawai bisa bertanggung jawab atas pekerjaan yang dilakukannya.

\section{Karakteristik Laporan Pertanggungjawaban}

Bambang (2013) menyatakan bahwa dalam rangka meningkatkan efisiensi, laporan pertanggungjawaban harus memiliki karakteristik berikut ini :

1. Laporan harus sesuai dengan struktur organisasi. Laporan ditujukan terutama kepada individu yang bertanggug jawab untuk mengendalikan aktivitas yang dicakup dalam laporan.

2. Laporan harus konsisten bentuk dan isinya setiap diterbitkan. Perubahan hanya dilakukan untuk alasan yang baik dan disertai penjelasan kepada pemakainya. Seringnya terjadi perubahan pada laporan akan membingungkan pemakai. Selain itu, perbandingan antar periode menjadi sulit dilakukan.

3. Laporan harus tepat waktu. Laporan harus disediakan untuk manajer pusat pertanggungjawaban secepat mungkin, di lain pihak, pembuatan laporan yang terlalu sering menimbulkan pemborosan. Oleh karena itu, perlu uji kelayakan dengan cara membandingkan biaya pelaporan pada berbagai interval dengan perkiraan biaya.

4. Laporan harus diterbitkan secara teratur. Keteraturan pelaporan meningkatkan kegunaannya. Manajer harus tahu kapan laporan akan disusun dan tersedia sehingga mereka dapat merencanakan dan mengendalikan aktivitasnya secara efektif.

5. Laporan harus mudah dipahami. Istilah akuntansi harus dijelaskan atau dimodifikasi agar mudah dipahami oleh pengguna. Untuk mengalokasikan biaya dan menganalisis penyimpangan, manajemen harus memiliki pengetahuan mengenai unsur yang akan dibebankan serta metode yang digunakan untuk menghitung tarif overhead.

6. Laporan memuat perincian yang memadai, tetapi tidak berlebihan. Jumlah dan jenis perincian tergantung pada tingkat manajemen yang menerima laporan. Laporan untuk manajer puncak tidak boleh terlalu banyak perincian yang tidak siap digunakan untuk mengevaluasi hasil secara keseluruhan. Sebaiknya laporan untuk manajer operasional harus memberikan perincian yang memadai agar memudahkan mereka dalam megidentifikasi inefisiensinya.

7. Laporan harus menyajikan data perbandingan (membandingkan anggaran atau standar yang sudah ditentukan dengan hasil sesungguhnya). Penyimpangan yang signifikan harus ditonjolkan sehingga manajer pusat pertanggungjawaban dapat mengidentifikasi masalah tersebut dengan cepat.

8. Laporan harus analitis. Akuntan harus memahami sifat aktivitas bisnis setiap unit organisasi agar dapat menyajikan informasi yang bermanfaat bagi setiap manajer yang bertanggung jawab. Analisis terhadap dokumen sumber, kartu jam kerja, bukti sisa bahan, order kerja, dan permintaan bahan dapat memberi informasi terkait dengan penyebab kinerja yang buruk. 


\section{Indikator Akuntansi pertanggungjawaban}

Menurut Mulyadi (2014) indikator akuntansi pertanggungjawaban adalah :

1. Pemahaman terhadap peranan akuntansi pertanggungjawaban.

2. Informasi akuntansi pertanggungjawaban.

3. Menetapkan suatu standar pengukuran.

4. Pemahaman umum terhadap pusat pendapatan, biaya, laba, dan investasi.

\section{Latar Belakang Pendidikan}

Latar belakang pendidikan mempunyai kaitan erat dengan hasil seleksi yang telah dilaksanakan oleh manajer sumber daya manusia. Dengan kata lain hasil seleksi dapat memperkuat dan meyakinkan manajer SDM untuk menempatkan orang yang bersangkutan pada tempat yang tepat. Latar belakang pendidikan dengan prestasi akademis yang diraihnya dapat menjadi acuan pemberian beban kerja dan tanggung jawab dalam melaksanakan pekerjaan (Tresna, 2015). Berdasarkan defenisi di atas maka pendidikan merupakan prestasi akademik yang telah dicapai oleh tenaga kerja selama mengikuti jenjang pendidikan harus mendapatkan pertimbangan dalam penempatan, dimana tenaga kerja seharusnya melaksanakan tugas dan pekerjaan serta mengemban wewenang dan tanggung jawab. Prestasi akademis yang menjadi pertimbangan bukan saja prestasi pada jenjang pendidikan terakhir, tetapi lebih dari itu dengan melihat perkembangan prestasi akademis sebelumnya.

Latar belakang pendidikan dapat dilihat dari dua sisi, yaitu kesesuaian antara bidang ilmu yang ditempuh dengan bidang tugas dan jenjang pendidikan (Tresna, 2015):

a. Jenjang Pendidikan

Berdasarkan tingkat perkembangan peserta didik, tujuan yang akan dicapai dan kemampuan yang dikembangkan dalam jenjang pendidikan formal terdiri dari:

1) Pendidikan atas, yaitu jenjang pendidikan lanjutan pendidikan menengah.

2) Pendidikan tinggi yaitu jenjang pendidikan setelah pendidikan atas yang mencakup program sarjana, magister, doktor, dan spesialis yang diselenggarakan oleh perguruan tinggi.

b. Spesifikasi atau Jurusan Keilmuan

Moeheriono (2014) menyebutkan bahwa Indikator dari pendidikan adalah:

a. Kedudukan pegawai adalah menunjukkan jabatan dari pegawai.

b. Kualitas kerja adalah mutu kerja yang dihasilkan oleh pegawai.

c. Peningkatan keahlian adalah menunjukkan kemajuan keahlian.

d. Manfaat bagi pegawai adalah keuntungan yang diperoleh pegawai.

e. Kecakapan adalah tindakan bijaksana dalam pekerjaan.

f. Keselarasan adalah dimana tingkat pendidikan sesuai dengan pekerjaan.

g. Semangat kerja adalah keinginan kerja yang tinggi yang ditunjukkan.

h. Disiplin kerja adalah ketepatan dan keakuratan dalam bekerja.

i. Kemampuan pegawai adalah daya upaya untuk melakukan pekerjaan.

j. Kemampuan sesuai pendidikan adalah upaya yang sesuai pendidikan.

\section{Penelitian Terdahulu}

Lusiana Kanji (2016) melakukan penelitian tentang pengaruh kejelasan sasaran anggaran, kinerja manajerial dan pelaporan/ pertanggungjawaban anggaran terhadap akuntabilitas kinerja instansi pemerintah daerah kabupaten enrekang. Hilarius Prima (2014) melakukan penelitian tentang 
pengaruh penerapan akuntansi pertanggungjawaban terhadap kinerja manajerial pada hotel berbintang di daerah istimewa Yogyakarta.

Dwisty Utari Yasmin (2017) melakukan penelitian tentang pengaruh penerapan akuntansi pertanggungjawaban dan pengendalian biaya terhadap kinerja manajerial (Studipada PT. INTI (Persero) Bandungdan PT. Telekomunikasi Indonesia, Tbk Bandung). Muhammad Teguh (2019) melakukan penelitian tentang Pengaruh Latar Belakang Pendidikan, Pengalaman, Pelatihan Dan Hubungan Antar Karyawan Terhadap Kinerja Mantri Pada Pt Bank Rakyat Indonesia (Persero) Tbk Cabang Samudera Banjarmasin.

\section{Pengaruh Kejelasan Sasaran Anggaran Terhadap Kinerja Manajerial}

Oleh sebab itu sasaran anggaran pemerintah daerah harus dinyatakan secara jelas, spesifik dan dapat dimengerti oleh mereka yang bertanggung jawab untuk melaksanakannya. Locke (1968) dalam Fitri (2015) menyatakan bahwa penetapan tujuan spesifik akan lebih produktif. Hal ini akan mendorong karyawan atau staf untuk melakukan pencapaian tujuan yang dikehendaki sehingga berimplikasi pada peningkatan kinerja.

Adapun hasil penelitian terdahulu yang dilakukan oleh Dharma (2014), bahwa adanya pengaruh positif antara kejelasan sasaran anggaran dan sasaran anggaran yang spesifik dengan kinerja manajerial. Pencapaian kinerja ini akan terkait dengan motivasi yang tinggi untuk membantu pegawai untuk mencapai kinerja yang diharapkan. Berdasarkan penjelasan di atas, maka hipotesis pertama yang akan di uji adalah sebagai berikut:

H1 : Kejelasan sasaran anggaran bepengaruh terhadap kinerja manajerial

\section{Pengaruh Akuntansi Pertanggungjawaban Terhadap Kinerja Manajerial}

Akuntansi pertanggungjawaban menurut Hansen dan Mowen yang diahli bahasakan oleh Deny (2014) akuntansi pertanggungjawaban adalah alat fundamental untuk pengendalian manajemen dan ditentukan melalui pemberian tanggungjawab. Idealnya sistem akuntansi pertanggungjawaban mencerminkan dan mendukung struktur dari sebuah organisasi, dimana secara umum sebuah perusahaan diatur menurut garis-garis pertanggungjawaban.

Dari pengertian tersebut, dapat disimpulkan bahwa syarat untuk dapat menerapkan akuntansi pertanggungjawaban, antara lain: struktur organisasi, anggaran, penggolongan biaya, penyusunan kode rekening perusahaan, dan sistem pelaporan biaya (Mulyadi, 2014). Dengan adanya hubungan antara akuntansi pertanggungjawaban dengan prestasi kerja, maka variabelvariabel yang terkandung dalam akuntansi pertanggungjawaban yaitu struktur organisasi, anggaran biaya, penggolongan biaya, penyusunan kode rekening, dan sistem pelaporan biaya yang ditetapkan dan laporan pertanggungjawaban juga mempunyai hubungan dengan prestasi kerja (Suwandi, 2011).

Berdasarkan definisi di atas dapat disimpulkan antara akuntansi pertanggungjawaban dengan kinerja manajerial terdapat hubungan yang erat. Sehingga bila akuntansi pertanggungjawaban dijalankan dengan baik dan lengkap, maka akan mempermudah dalam menilai kinerja manajerial setiap departemen yaitu dengan membandingkan selisih (variance) dengan anggaran yang ditetapkan. Hal ini didukung oleh penelitian yang dilakukan oleh Hilarius Prima (2014) ditemukan adanya pengaruh penerapan akuntansi pertanggungjawaban terhadap kinerja manajerial. Penjelasan di atas dapat ditarik hipotesis dua yaitu sebagai berikut:

H2: Akuntansi Pertanggungjawaban Berpengaruh terhadap Kinerja Manajerial 


\section{Pengaruh Latar Belakang Pendidikan terhadap Kinerja Manajerial}

Latar belakang pendidikan mempunyai hubungan yang erat dengan hasil seleksi yang telah dilaksanakan oleh manajer sumber daya manusia. Dengan kata lain hasil seleksi dapat memperkuat dan meyakinkan manajer SDM untuk menempatkan orang yang bersangkutan pada tempat yang tepat. Latar belakang pendidikan dengan prestasi akademis yang diraihnya dapat menjadi acuan pemberian beban kerja dan tanggung jawab dalam melaksanakan pekerjaan (Tresna, 2015).

Prestasi akademik yang telah dicapai oleh tenaga kerja selama mengikuti jenjang pendidikan harus mendapatkan pertimbangan dalam penempatan, dimana tenaga kerja seharusnya melaksanakan tugas dan pekerjaan serta mengembangkan wewenang dan tanggung jawab. Prestasi akademis yang menjadi pertimbangan bukan saja prestasi pada jenjang pendidikan terakhir, tetapi lebih dari itu dengan melihat perkembangan prestasi akademis sebelumnya. Latar belakang pendidikan dengan prestasi akademis yang diraihnya dapat menjadi acuan pemberian beban kerja dan tanggung jawab dalam melaksanakan pekerjaan (Tresna, 2015). Berdasarkan pernyataan tersebut, maka hipotesis tiga yaitu sebagai berikut:

H3: Latar belakang pendidikan berpengaruh terhadap kinerja manajerial

\section{Kerangka Konseptual}

Berdasarkan penjelasan sebelumnya, maka kerangka Konseptual penelitian ini yaitu sebagai berikut :

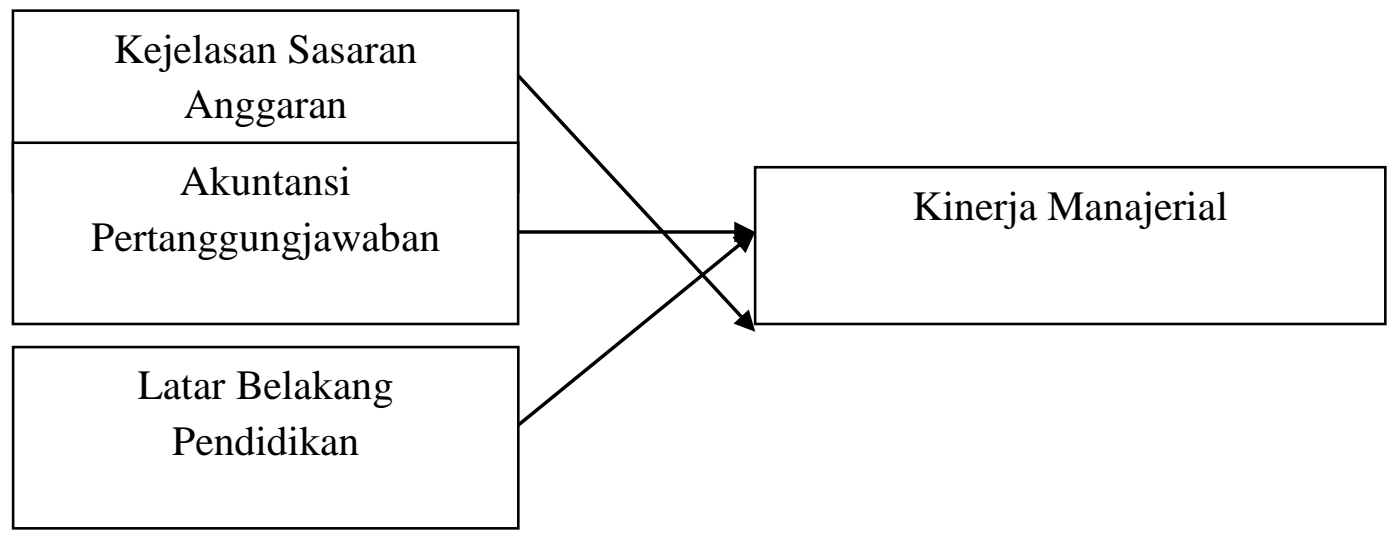

Gambar 2.1

Kerangka Konseptual

\section{METODE PENELITIAN}

Dalam penelitian ini menggunakan desain kausalitas. Menurut Sugiyono (2014) penelitian desain kausal adalah penelitian yang berguna untuk menganalisis hubungan-hubungan antara satu variabel dengan variabel lainya. Sifat hubungan-hubungan yang mungkin terjadi antara variabel-variabel adalah simetris, asimetris dan timbal balik.

Dalam penelitian ini yang menjadi populasi adalah keseluruhan atau himpunan objek dengan ciri yang sama, populasi dapat berupa himpunan orang, benda hidup atau benda mati (Mangguluang, 2016). Berdasarkan pengertian tersebut, maka populasi dari penelitian ini adalah seluruh pegawai bagian anggaran satuan kerja Kementerian Perindustrian Padang (Studi Kasus Baristand Padang, BDI, ATIP, SMTI, SMAK). 
Pada penelitian ini menggunakan teknik pengambilan sampel dengan metode sampling jenuh (Metode Sensus). Adapun jumlah sampel penelitian ini 35 orang yang terdiri dari Baristand Padang 9 orang, BDI 7 orang, ATIP 7 orang, SMTI 6 orang, SMAK 6 orang di bagian anggaran disekitar Satuan Kerja Kementerian Perindustrian Padang.

\section{Metode Analisis Data}

Penelitian ini menggunakancanalisis regresi berganda. Dalam hal menganalisis data agar dapat memberikan gambaran yang ringkas dan jelas mengenai mengenai variabel yang diteliti digunakan statistik deskriptif. Pengujian asumsi klasik dalam penelitian ini adalah adalah uji normalitas, uji heterokedasitas, dan uji multikolinieritas.

\section{HASIL DAN PEMBAHASAN \\ Gambaran Umum Objek Penelitian}

Populasi dalam penelitian ini adalah seluruh pegawai bagian anggaran satuan kerja Kementerian Perindustrian Padang (Baristand Padang, BDI, ATIP, SMTI, SMAK). Sampel yang digunakan penelitian ini adalah dengan menggunakan rumus metode sensus sebanyak 35 sampel.

\section{Demografi Responden}

Dari hasil penelitian yang telah dilakukan, dapat dilihat karakteristik dari seluruh responden yang menjadi sampel dalam penelitian ini, antara lain adalah karakteristik responden berdasarkan jenis kelamin, umur, tingkat pendidikan, dan jenis pekerjaan.

\section{Uji Validitas}

Berdasarkan perhitungan nilai corrected item-total colleration yang diperoleh, menunjukkan hasil bahwa nilai terkecil corrected item-total colleration dari masing-masing item variabel $\mathrm{X}_{1}$, $\mathrm{X}_{2}, \mathrm{X}_{3}$, dan $\mathrm{Y}$ berada diatas $\mathrm{r}_{\text {tabel. }}$. Oleh karena $\mathrm{r}_{\text {hitung }}>\mathrm{r}_{\text {tabel }}$ maka butir pertanyaan tersebut dapat dikatakan valid. Jadi dapat disimpulkan bahwa seluruh item variabel $\mathrm{X}_{1}, \mathrm{X}_{2}, \mathrm{X}_{3}$, dan $\mathrm{Y}$ adalah valid.

\section{Uji Reliabilitas}

Dari perhitungan yang dilakukan diperoleh nilai Cronbach's Alpha. Hasil pengujian reliabilitas dapat disimpulkan bahwa semua item pertanyaan reliable. Semua variabel reliable disebabkan karena hasil alpha besar dari 0,3640 (untuk n=30 r table=0,3640). Sehingga semua item ketiga varabel penelitian yaitu kejelasan sasaran anggaran, akuntansi pertanggung jawaban dan kinerja manajerial dilanjutkan penelitian. 


\section{Uji Asumsi Klasik}

Uji Normalitas

Tabel 1

Uji Normalitas

\begin{tabular}{|c|c|c|c|c|c|}
\hline & & $\begin{array}{c}\text { KINERJA } \\
\text { MANAJERIAL }\end{array}$ & $\begin{array}{l}\text { KEJELASAN } \\
\text { SASARAN } \\
\text { ANGGARAN }\end{array}$ & $\begin{array}{l}\text { AKUNTANSI } \\
\text { PERTANGGU } \\
\text { NG JAWABAN }\end{array}$ & PENDIDIKAN \\
\hline $\mathrm{N}$ & & 35 & 35 & 35 & 35 \\
\hline \multirow[t]{2}{*}{ Normal Parameters ${ }^{a, b}$} & Mean & 53,54 & 52,23 & 33,54 & 32,66 \\
\hline & Std. Deviation & 5,721 & 5,369 & 3,943 & 4,505 \\
\hline \multirow{3}{*}{ Differences } & Absolute & ,132 & , 130 &, 140 & ,122 \\
\hline & Positive & ,132 & ,126 &, 140 & ,122 \\
\hline & Negative &,- 099 &,- 130 &,- 099 &,- 118 \\
\hline Kolmogorov-Smirnov Z & & ,782 & ,770 & ,831 & ,724 \\
\hline Asymp. Sig. (2-tailed) & &, 574 &, 593 & ,494 & 671 \\
\hline
\end{tabular}

a. Test distribution is Normal.

b. Calculated from data.

Hasil pengujian prasyarat normalitas diketahui bahwa nilai Asym.Sig (2-tailed) untuk variabel kinerja manajerial $(\mathrm{Y}) 0,574$, variabel Kejelasan sasaran anggaran $\left(\mathrm{X}_{1}\right)$ sebesar 0,593, variabel akuntansi pertanggungjawaban $\left(\mathrm{X}_{2}\right)$ sebesar 0,494 dan pendidikan $\left(\mathrm{X}_{3}\right)$ sebesar 0,671 dari semua variabel penelitian nilainya lebih besar dari tingkat signifikan yang digunakan pada penelitian ini $(\alpha=0,05)$. Dengan demikian dapat disimpulkan bahwa semua variabel penelitian berdistribusi normal, dengan demikian analisis regresi linear berganda dapat dilaksanakan karena data telah berdistribusi normal.

\section{Uji Multikolinearitas}

Uji multikolonearitas bertujuan untuk menguji apakah model regresi yang ditemukan terdapat kolerasi antar variabel bebas.Untuk mengujinya, dilakukan dengan melihat nilai Variance Inflantions Factor (VIF). Jika nilai VIF $<10$ dan tolerance $>0,1$, maka variabel dapat dikatakan bebas multikolonearitas.

Tabel 2

\section{Hasil Uji Multikolonieritas}

Coefficierits

\begin{tabular}{|c|c|c|c|c|c|c|c|c|}
\hline \multirow[b]{2}{*}{ Mode } & & \multicolumn{2}{|c|}{$\begin{array}{l}\text { Unstandardized } \\
\text { Coefficients }\end{array}$} & \multirow{2}{*}{$\begin{array}{c}\begin{array}{c}\text { Standardize } \\
\text { Coefficients }\end{array} \\
\text { Beta } \\
\end{array}$} & \multirow[b]{2}{*}{$t$} & \multirow[b]{2}{*}{ Sig. } & \multicolumn{2}{|c|}{ Collinearity Statistics } \\
\hline & & B & Std. Erro & & & & Tolerance & VIF \\
\hline 1 & (Constant) & 5,192 & 1,297 & & 4,003 &, 000 & & \\
\hline & $\begin{array}{l}\text { KEJELASAN } \\
\text { SASARAN ANGGARAN }\end{array}$ & ,125 &, 045 & ,118 & 2,771 &, 009 & ,251 & 3,992 \\
\hline & $\begin{array}{l}\text { AKUNTANSI } \\
\text { PERTANGGUNG } \\
\text { JAWABAN }\end{array}$ & ,896 & , 160 & ,617 & 5,593 &, 000 &, 037 & 6,818 \\
\hline & PENDIDIKAN & ,359 & ,136 & 276 & 2,647 & ,012 & ,042 & 3,960 \\
\hline
\end{tabular}

a. Dependent Variable: KINERJA MANAJERIAL

Hasil pengujian prasyarat uji multikolonieritas diketahui bahwa nilai tolerance dari Collinearity Statistics < 1 (satu) dan nilai VIF (Variance Inflation Factor) di bawah 10 (sepuluh). Hal ini menunjukkan bahwa tidak hubungan yang berarti antara sesama variabel bebas. Oleh karena itu 
dapat disimpulkan bahwa data hasil penelitian ini tidak mengalami kasus multikolonieritas antara sesama variabel bebas, sehingga pengolahan data dengan regresi linear berganda dapat dilanjutkan.

\section{Uji Heteroskedastisitas}

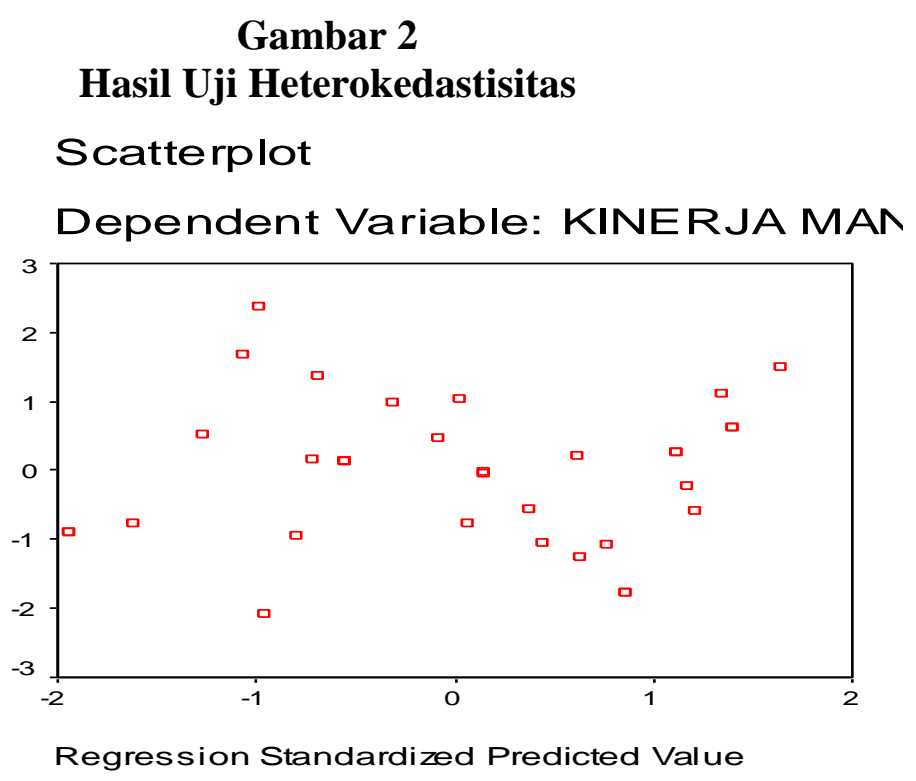

\section{Uji Autokorelasi}

Tabel 3

Uji Autokorelasi

Model Summary

\begin{tabular}{|l|r|r|r|r|c|}
\hline Model & \multicolumn{1}{|c|}{$\mathrm{R}$} & R Square & $\begin{array}{c}\text { Adjusted } \\
\text { R Square }\end{array}$ & $\begin{array}{r}\text { Std. Error of } \\
\text { the Estimate }\end{array}$ & $\begin{array}{c}\text { Durbin-W } \\
\text { atson }\end{array}$ \\
\hline 1 &, $993^{\mathrm{a}}$ &, 985 &, 984 &, 758 & 1,846 \\
\hline
\end{tabular}

a. Predictors: (Constant), PENDIDIKAN, KEJELASAN SASARAN ANGGARAN, AKUNTANSI PERTANGGUNG JAWABAN

b. Dependent Variable: KINERJA MANAJERIAL

Pada Uji Autokorelasi dapat disimpulkan bahwa tidak terjadi kasus autokorelasi karena nilai Durbin Waston mendekati 2 atau kecil dari 2.

\section{Model Regersi Linear Berganda}

Model regresi berganda dilakukan untuk menyatakan hubungan fungsional variabel bebas dan variabel terikat. Analisis regresi berganda dilakukan dengan menggunakan pengolahan dari program SPSS 16. 
Tabel 4

Hasil Analisis Regresi Linear Berganda

\begin{tabular}{|c|c|c|c|c|c|c|}
\hline \multicolumn{7}{|c|}{ Coefficients } \\
\hline \multirow[b]{2}{*}{ Model } & & \multicolumn{2}{|c|}{$\begin{array}{c}\text { Unstandardized } \\
\text { Coefficients }\end{array}$} & \multirow{2}{*}{$\begin{array}{c}\begin{array}{c}\text { Standardized } \\
\text { Coefficients }\end{array} \\
\text { Beta }\end{array}$} & \multirow[b]{2}{*}{$\mathrm{t}$} & \multirow[b]{2}{*}{ Sig. } \\
\hline & & $\mathrm{B}$ & Std. Error & & & \\
\hline 1 & (Constant) & 5,192 & 1,297 & & 4,003 &, 000 \\
\hline & $\begin{array}{l}\text { KEJELASAN } \\
\text { SASARAN ANGGARAN }\end{array}$ & , 125 & ,045 & ,118 & 2,771 & ,009 \\
\hline & $\begin{array}{l}\text { AKUNTANSI } \\
\text { PERTANGGUNG } \\
\text { JAW ABAN }\end{array}$ & ,896 & , 160 & ,617 & 5,593 &, 000 \\
\hline & PENDIDIKAN & ,359 & ,136 & ,276 & 2,647 &, 012 \\
\hline
\end{tabular}

a. Dependent Variable: KINERJA MANAJERIAL

Angka yang dihasilkan dalam persamaan regresi berganda tersebut dapat dijelaskan sebagai berikut:

\section{Konstanta ( $\alpha)$}

Nilai konstanta sebesar 5.192, artinya jika kejelasan sasaran anggaran, akuntansi pertanggungjawaban dan pendidikan nilainya adalah $0(\mathrm{X} 1=\mathrm{X} 2=\mathrm{X} 3=0)$ maka nilai kinerja manajerial di Satuan Kerja Kementerian Perindustrian Padang adalah sebesar konstanta yaitu 5,192 satuan.

\section{Koefisien Regresi $\boldsymbol{\beta}_{1} \mathbf{X}_{1}$}

Koefisien kejelasan sasaran anggaran adalah sebesar 0,125 artinya kejelasan sasaran anggaran positif terhadap kinerja manajerial di Satuan Kerja Kementerian Perindustrian Padang, dimana jika kejelasan sasaran anggaran meningkat satu satuan maka kinerja manajerial di Satuan Kerja Kementrian Perindustrian Padang meningkat sebesar 0,125 satuan.

\section{Koefisien Regresi $\boldsymbol{\beta}_{2} \mathbf{X}_{2}$}

Koefisien akuntansi pertanggungjawaban adalah sebesar 0.896 artinya akuntansi pertanggungjawaban berpengaruh positif terhadap kinerja manajerial di Satuan Kerja Kementerian Perindustrian Padang. Dimana jika akuntansi pertanggungjawaban meningkat satu satuan maka kinerja manajerial di Satuan Kerja Kementerian Perindustrian Padang akan meningkat sebesar 0.896 satuan.

\section{Koefisien Regresi $\beta_{3} \mathbf{X}_{3}$}

Koefisien Latar Belakang pendidikan adalah sebesar 0,359 artinya pendidikan berpengaruh positif terhadap kinerja manajerial di Satuan Kerja Kementerian Perindustrian Padang. Dimana jika pendidikan meningkat satu satuan maka kinerja manajerial di Satuan Kerja Kementerian Perindustrian Padang akan meningkat sebesar 0,359 satuan.

\section{Uji Model}

\section{Uji Koefisien Determinasi}

Koefisien determinasi berguna untuk melihat kontribusi pengaruh variabel bebas terhadap variabel terikat. Untuk mengetahui seberapa besar kontribusi kejelasan sasaran anggaran, dan akuntansi pertanggungjawaban terhadap kinerja Satuan Kerja Kementerian Perindustrian Padang. 


\section{Tabel 5}

\section{Uji R Square}

Model Summary

\begin{tabular}{|l|r|r|r|r|}
\hline Model & \multicolumn{1}{|c|}{$\mathrm{R}$} & R Square & $\begin{array}{c}\text { Adjusted } \\
\text { R Square }\end{array}$ & $\begin{array}{r}\text { Std. Error of } \\
\text { the Estimate }\end{array}$ \\
\hline 1 &, $993^{\mathrm{a}}$ &, 985 &, 984 &, 758 \\
\hline
\end{tabular}

a. Predictors: (Constant), PENDIDIKAN, KEJELASAN SASARAN ANGGARAN, AKUNTANSI PERTANGGUNG JAW ABAN

Sumber : Lampiran Hasil Pengolahan Data SPSS, 2019

Berdasarkan uji Adjusted R-Square ditemukan nilai koefisien determinasi kinerja Satuan Kerja Kementerian Perindustrian Padang ditunjukan dengan nilai Adjust $R$ Square sebesar 0,984, hal ini berarti besarnya kontribusi pengaruh kejelasan sasaran anggaran, akuntansi pertanggungjawabab dan pendidikan terhadap kinerja Satuan Kerja Kementerian Perindustrian Padang 98,4\% sedangkan sisanya dipengaruhi oleh variabel lain seperti lingkungan kerja, insentif, komitmen kerja dan lainnya.

\section{Uji T}

Uji t digunakan untuk melihat pengaruh dari manising-masing variabel bebas terhadap variabel independen dengan variabel dependent. Dengan bantuan program SPSS versi 22 diketahui nilai t hitung pada tabel 6 sebagai berikut :

Tabel 6

Uji t

Coefficients

\begin{tabular}{|c|c|c|c|c|c|c|}
\hline \multirow[b]{2}{*}{ Mod } & & \multicolumn{2}{|c|}{$\begin{array}{l}\text { Unstandardized } \\
\text { Coefficients }\end{array}$} & \multirow{2}{*}{$\begin{array}{c}\begin{array}{c}\text { Standardized } \\
\text { Coefficients }\end{array} \\
\text { Beta }\end{array}$} & \multirow[b]{2}{*}{$t$} & \multirow[b]{2}{*}{ Sig. } \\
\hline & & $\mathrm{B}$ & Std. Error & & & \\
\hline \multirow[t]{4}{*}{1} & (Constant) & 5,192 & 1,297 & & 4,003 &, 000 \\
\hline & $\begin{array}{l}\text { KEJELASAN } \\
\text { SASARAN ANGGARAN }\end{array}$ & , 125 & ,045 & ,118 & 2,771 & ,009 \\
\hline & $\begin{array}{l}\text { AKUNTANSI } \\
\text { PERTANGGUNG } \\
\text { JAWABAN }\end{array}$ & ,896 & , 160 & ,617 & 5,593 & ,000 \\
\hline & PENDIDIKAN & 359 & 136 & 276 & 2,647 & 012 \\
\hline
\end{tabular}

a. Dependent Variable: KINERJA MANAJERIAL

Sumber: Lampiran Hasil Pengolahan Data SPSS, 2019

1. Nilai $\mathrm{t}$ hitung 2.771 dan nilai $\left(\mathrm{sig}=0,009<0,05\right.$ ). Dengan $\mathrm{df}=35-3=32$ diperoleh $\mathrm{t}_{\text {tabel }}$ sebesar 1.694, dari hasil di atas dapat dilihat bahwa thitung $>t_{\text {tabel }}$ atau $2.771>1.694$, maka variabel kejelasan sasaran anggaran berpengaruh terhadap kinerja manajerial di Satuan Kerja Kementerian Perindustrian Padang.

2. Nilai t hitung 5.593 dan nilai $(\mathrm{sig}=0,000<0,05)$. Dengan $\mathrm{df}=35-3=32$ diperoleh tabel sebesar 1.694, dari hasil di atas dapat dilihat bahwa thitung $>t_{\text {tabel }}$ atau $5.592>1.694$, maka variabel akuntansi pertanggungjawaban berpengaruh terhadap kinerja manajerial di Satuan Kerja Kementerian Perindustrian Padang. 
3. Nilai t hitung 2.647 dan nilai ( $\operatorname{sig}=0,012<0,05$ ). Dengan $\mathrm{df}=35-3=32$ diperoleh $\mathrm{t}_{\text {tabel }}$ sebesar 1.694, dari hasil di atas dapat dilihat bahwa $t_{\text {hitung }}>t_{\text {tabel }}$ atau $5.592>1.694$, maka variabel pendidikan berpengaruh terhadap kinerja manajerial di Satuan Kerja Kementerian Perindustrian Padang.

\section{Uji F}

Uji $\mathrm{F}$ digunakan untuk melihat pengaruh secara keseluruhan dari variabel independen dengan variabel dependent. Dengan bantuan program SPSS versi 22 diketahui nilai F hitung pada tabel Anova sebagai berikut:

Tabel 7

Hasil Uji Kelayakan (Uji F)

ANOVA

\begin{tabular}{|c|c|c|c|c|c|c|}
\hline Model & & $\begin{array}{l}\text { Sum of } \\
\text { Squares }\end{array}$ & df & Mean Square & $\mathrm{F}$ & Sig. \\
\hline \multirow[t]{3}{*}{1} & Regression & 1247,257 & 3 & 415,752 & 723,770 &, $000^{\mathrm{a}}$ \\
\hline & Residual & 18,382 & 32 &, 574 & & \\
\hline & Total & 1265,639 & 35 & & & \\
\hline
\end{tabular}

a. Predictors: (Constant), PENDIDIKAN, KEJELASAN SASARAN ANGGARAN, AKUNTANSI PERTANGGUNG JAWABAN

b. Dependent Variable: KINERJA MANAJERIAL

Sumber: Lampiran Hasil Pengolahan Data SPSS, 2019

Berdasarkan uji $\mathrm{F}$ diketahui bahwa nilai $\mathrm{F}$ hitung 723.770 dengan nilai signifikansi sebesar 0,000 $(\mathrm{p}<0,05)$. Hal ini berarti secara bersama-sama variabel kejelasan sasaran anggaran, akuntansi pertanggungjawaban dan pendidikan berpengaruh terhadap kinerja manajerial di Satuan Kerja Kementerian Perindustrian Padang.

\section{PEMBAHASAN}

Pembahasan dalam penelitian ini bertujuan untuk menjelaskan hasil penelitian sesuai dengan tujuan penelitian. Hasil pembahasan akan diuraikan dibawah ini.

\section{Pengaruh Kejelasan Sasaran Anggaran terhadap Kinerja Manjajerial}

Nilai t hitung 2.771 dan nilai ( $\operatorname{sig}=0,009<0,05$ ). Dengan $\mathrm{df}=35-3=32$ diperoleh $\mathrm{t}_{\text {tabel }}$ sebesar 1.694, dari hasil di atas dapat dilihat bahwa $t_{\text {hitung }}>t_{\text {tabel }}$ atau $2.771>1.694$, maka variabel kejelasan sasaran anggaran berpengaruh terhadap kinerja manajerial di Satuan Kerja Kementerian Perindustrian Padang. Skor rata-rata variabel kejelasan sasaran anggaran di Satuan Kerja Kementerian Perindustrian Padang yang terdiri-dari 12 pertanyaan, dimana nilai rata-rata 3,72 dengan Tingkat Capaian Responden (TCR) sebesar 74,48\%. Hal ini menunjukan bahwa variabel kejelasan sasaran anggaran di Satuan Kerja Kementerian Perindustrian Padang dalam kategori Baik.

\section{Pengaruh Akuntansi Pertanggungjawaban terhadap Kinerja Manjajerial}

Nilai thitung 5.593 dan nilai ( $\mathrm{sig}=0,000<0,05$ ). Dengan $\mathrm{df}=35-3=32$ diperoleh $\mathrm{t}_{\text {tabel }}$ sebesar 1.694, dari hasil di atas dapat dilihat bahwa $t_{\text {hitung }}>\mathrm{t}_{\text {tabel }}$ atau $5.592>1.694$, maka variabel 
akuntansi pertanggungjawaban berpengaruh terhadap kinerja manajerial di Satuan Kerja Kementerian Perindustrian Padang. Skor rata-rata variabel akuntansi pertanggungjawaban di Satuan Kerja Kementerian Perindustrian Padang yang terdiri-dari 8 pertanyaan, dimana nilai rata-rata 3,95 dengan Tingkat Capaian Responden (TCR) sebesar 78,93\%. Hal ini menunjukan bahwa variabel akuntansi pertanggungjawaban di Satuan Kerja Kementerian Perindustrian Padang dalam kategori Baik.

\section{Pengaruh Pendidikan terhadap Kinerja Manjajerial}

Nilai thitung 2.647 dan nilai ( $\mathrm{sig}=0,012<0,05$ ). Dengan $\mathrm{df}=35-3=32$ diperoleh $\mathrm{t}_{\text {tabel }}$ sebesar 1.694, dari hasil di atas dapat dilihat bahwa $t_{\text {hitung }}>\mathrm{t}_{\text {tabel }}$ atau $5.592>1.694$, maka variabel pendidikan berpengaruh terhadap kinerja manajerial di Satuan Kerja Kementerian Perindustrian Padang. Skor rata-rata variabel pendidikan di Satuan Kerja Kementerian Perindustrian Padang yang terdiri-dari 10 pertanyaan, dimana nilai rata-rata 3,27 dengan Tingkat Capaian Responden (TCR) sebesar 65,31\%. Hal ini menunjukan bahwa variabel pendidikan di Satuan Kerja Kementerian Perindustrian Padang dalam kategori Baik.

\section{Pengaruh Kejelasan Sasaran Anggaran dan Akuntansi Pertanggungjawaban Secara Bersama-Sama terhadap Kinerja Manajerial}

Berdasarkan uji $\mathrm{F}$ diketahui bahwa nilai $\mathrm{F}$ hitung 723.770 dengan nilai signifikansi sebesar 0,000 $(\mathrm{p}<0,05)$. Hal ini berarti secara bersama-sama variabel kejelasan sasaran anggaran, akuntansi pertanggungjawaban dan pendidikan berpengaruh terhadap kinerja manajerial di Satuan Kerja Kementerian Perindustrian Padang. Skor rata-rata variabel kinerja manajerial di Satuan Kerja Kementerian Perindustrian Padang yang terdiri-dari 16 pertanyaan, dimana nilai rata-rata 3,72 dengan Tingkat Capaian Responden (TCR) sebesar 74,48\%. Hal ini menunjukan bahwa variabel kinerja manajerial di Satuan Kerja Kementerian Perindustrian Padang dalam kategori Baik.

\section{KESIMPULAN DAN SARAN \\ Kesimpulan}

Penelitian ini meneliti tentang Pengaruh Kejelasan Sasaran Anggaran Dan Akuntansi Pertanggungjawaban Terhadap Kinerja Manajerial Di Satuan Kerja Kementerian Perindustrian Padang. Setelah dilakukan penelitian terhadap 35 orang pegawai yang bekerja di Satuan Kerja Kementerian Perindustrian Padang diperoleh hasil sebagai berikut :

1. Nilai $t$ hitung 2.771 dan nilai ( $\mathrm{sig}=0,009<0,05$ ). Dengan $\mathrm{df}=35-3=32$ diperoleh $\mathrm{t}_{\text {tabel }}$ sebesar 1.694, dari hasil di atas dapat dilihat bahwa $t_{\text {hitung }}>t_{\text {tabel }}$ atau $2.771>1.694$, maka variabel kejelasan sasaran anggaran berpengaruh terhadap kinerja manajerial di Satuan Kerja Kementerian Perindustrian Padang.

2. Nilai t hitung 5.593 dan nilai ( $\mathrm{sig}=0,000<0,05$ ). Dengan $\mathrm{df}=35-3=32$ diperoleh tabel sebesar 1.694, dari hasil di atas dapat dilihat bahwa $t_{\text {hitung }}>t_{\text {tabel }}$ atau $5.592>1.694$, maka variabel akuntansi pertanggungjawaban berpengaruh terhadap kinerja manajerial di Satuan Kerja Kementerian Perindustrian Padang.

3. Nilai t hitung 2.647 dan nilai ( $\mathrm{sig}=0,012<0,05$ ). Dengan $\mathrm{df}=35-3=32$ diperoleh $\mathrm{t}_{\text {tabel }}$ sebesar 1.694, dari hasil di atas dapat dilihat bahwa thitung $>t_{\text {tabel }}$ atau $5.592>1.694$, maka variabel pendidikan berpengaruh terhadap kinerja manajerial di Satuan Kerja Kementerian Perindustrian Padang. 


\section{Saran}

1. Pada aspek aluntansi pertanggung jawaban Satuan Kerja Kementerian Perindustrian Padang sebaiknya ada pertanggungjawaban dari atas ke bawah agar bisa terlihat siapa yang harus bertanggung jawab atas anggaran yang telah ditetapkan. Hasil penelitian memperlihaatkan akuntansi pertanggung jawaban akan memberikan kontribusi, oleh sebab itu jikan instansi ingin meningkatkan kinerja maka perlu lebih dijelaskan tupoksi masing-masing pada Satuan Kerja Kementerian Perindustrian Padang.

2. Hasil penelitian memperlihatkan latar belakang pendidikan memberikan kontribusi besar, oleh sebab itu jikan instansi ingin meningkatkan kinerja maka perlu memilih pegawai yang memiliki kualitifikaasi pendidikan yang sesuai dengan bidang pekerjaannya.

3. Pada aspek kejelasan sasaran anggaran sebaiknya Satuan Kerja Kementerian Perindustrian Padang memberikan kejelasan sasaran anggaran agar karyawan dapat menjalankan anggaran yang ditetapkan tersebut. Hasil penelitian memperlihatkan kejelasan sasaran anggaran akan memberikan kontribusi ketiga terbesar daari variaabel sebelumnya. Oleh sebab itu jika instansi ingin meningkatkan kinerja maka perlu lebih dijelaskan sasaran anggaran kepada pegawai pengelola keuangan.

4. Sebaiknya instansi lebih meningkatkan kinerja manajerial agar tercipta tujuan instansi yang jelas. Adanya kaitan kejelasan sasaran anggatan dan akuntansi pertanggung jawaban terhadap kinerja manajerial sebaiknya lebih memberikan kejelasan sasaran kepada karyawan bagian keuangan dan adanya pertanggung jawaban dari masing-masing karyawan.

\section{DAFTAR PUSTAKA}

Abdul. (2011). Akuntansi Sektor Publik, Akuntansi keuangan Daerah, Edisi 3. Jakarta:Salemba Empat.

Agussalim, M. (2016). Metodologi Penelitian. Ekasakti Press: Universitas Ekasakti Padang.

Anthony \& Govindarajan. (2014). Management Control System. Eleventh Edition. New York: McGraw Hill. Dialih bahasakan oleh F.X.

Afilu, H. (2017). Pengaruh Kejelasan Sasaran Anggaran, Pengendalian Akuntansi, Sistem Pelaporan Terhadap Akuntabilitas Kinerja SKPD di Merauke. ISBN: 978-979-3649-81-8.

Badric S., et.al, (2013). Budgeting: 5th Edition. Dialih bahasakan oleh Purwati ningsih dan Maudy Warouw.

Arifuddin. (2016). Articipation Andgoalclarity Budgetto Performance Apparatuswith Comitmen and Cultural Organizationas A Moderating Variabel.

Bambang. (2013). Sistem Informasi Manajemen Berbasis Komputer. Jakarta: Rineka Cipta.

Damastu. (2017). Penganggaran Sektor Publik. Jakarta: Bayu media publishing.

Dharma. (2014). Kejelasan sasaran anggaran dan sasaran anggaran spesifik dengan kinerja manajerial.

Dwisty, U., Y, (2017). Pengaruh Penerapan Akuntansi Pertanggungjawaban Dan Pengendalian Biaya Terhadap Kinerja Manajerial (Studi pada PT. INTI (Persero) Bandung dan PT. Telekomunikasi Indonesia, Tbk Bandung). Jurnal. 15(7). ISSN 8224.3811.

Emili. (2014). Teori, Konsep, dan Aplikasi Akuntansi Sektor Publik, edisi ke-2. Jakarta: Salemba empat.

Fathul J. (2016). The effect of budget goal clarity, organizational commitment, accounting control, and adherence to laws on the perception of government performance of Central Lombok Regency. 6(1). 
Febian. (2016). Pengaruh Kejelasan Sasaran Anggaran, Kualitas Sumberdaya Manusia dan Komitmen Organisasi Terhadap Kinerja Pengelolaan Keuangan Daerah Di Lingkungan Pemerintah Cirebon. Jurnal 31(4), ISSN 1144.3877.

Fitri. (2015). Pengaruh Kejelasan Sasaran Anggaran, Akuntansi Pertanggung Jawaban, Pengendalian Akuntansi dan Sistem Pelaporan terhadap Kinerja Manajerial Instansi Pemerintah Daerah Kota Jambi. Simposium Nasional Akuntansi 13.Jambi.

Ghozali, I. (2011). Aplikasi Analalisis Multivariat dengan SPSS. Semarang: Universitas Diponegoro.

Idris. (2016). Analisis Data Kuantitatif. UNP: Padang.

Instruksi Presiden Republik Indonesia. Undang-Undang No. 7 Tahun 1999, Tentang Akuntabilitas Kinerja Instansi Pemerintah.

Hanang. 2016. Pengaruh Kejelasan Sasaran Anggaran dan Evaluasi Anggaran Terhadap Kinerja Manajerial dengan Sistem Pengendalian Internal.

Hariadi. (2012). Akuntansi Sektor Publik, Suatu Pengantar. Jakarta: Earlangga.

Halim. (2013). Anggaran Sektor Publik. Jakarta: Salemba Empat.

Hilarius, P. (2014). Pengaruh Penerapan Akuntansi Pertanggungjawaban Terhadap Kinerja Manajerial Pada Hotel Berbintang di Daerah Istimewa Yogyakarta (Survei pada Hotel Berbintang 2-5 di Daerah Istimewa Yogyakarta). Jurnal, 9(8). ISSN 6664.3821.

Humaidi. (2017). The Effect of Clarity Goal Budgeting, Budgeting Partipation, Reporting System and Accounting Control of the Accountabelity Performance of The Public High School Throughout the Lombok Island. International Conference and Call for Papers, Jember.

Kahnerman, D. and A. Tversky (1979).Prospect Theory: An Analysis of Decision Under Risk. Econometrica, 47: 263-291.

Kenis. (2010). Management Control System. Eleventh Edition. New York: McGraw Hill.

Lestari, A. 2016. Pengaruh Latar Belakang Pendidikan dan Pengalaman Kerja Terhadap Peningkatan Kinerja Karyawan pada BNI Syariah Cabang Cirebon.

Linda, D., K. (2010). Pengaruh Penerapan Akuntansi Pertanggungjawaban Terhadap Kinerja Manajerial Dengan Motivasi Sebagai Variabel Intervening (Survei Pada PT Taman Wisata Candi Borobudur, Prambanan,Dan Ratu Boko). Jurnal. 22(13). ISSN 7754.3877.

Lusiana, K. (2016). Pengaruh Kejelasan Sasaran Anggaran, Kinerja Manajerial Dan Pelaporan atau Pertanggungjawaban Anggaran Terhadap Akuntabilitas Kinerja Instansi Pemerintah Daerah Kabupaten Enrekang. Jurnal. 17 (2). ISSN 8954.3811.

Mahoney. (2013). Budgeting: Profit, Planning and Control. 5th Edition. Dialih bahasakan oleh Purwatiningsih dan Maudy Warouw.

Maria, Niken Setyarini. 2013. Pengaruh Partisipasi Anggaran Terhadap Kinerja Manajerial Dengan Komitmen Organisasi Sebagai Variabel Intervening Pada Bank Perkreditan Rakyat.

Metha. (2016). Assesing the Impact of Budgetary Participation on Budgetary Outcomes : The Role of Information Technology for Enhanched Communication and Activity-Based Costing. Journal Management Control. Verlag Berlin Heidelberg.

Mulyadi dan Setyawan. (2014). Sistem Perencanaan dan Pengendalian Manajemen. Jakarta : Salemba Empat.

Moeheriono. (2014). Kompetensi Pegawai dalam Organisasi. Jakarta. Bumi Aksara. 
Nadirsyah., B, U. 2012. Pengaruh Penerapan Total Quality Management terhadap Kinerja Manajerial dengan Budaya Organisasi, Sistem Pengukuran Kinerja dan Sistem Penghargaan sebagai Variabel Moderating (Studi Empiris pada Manajer Bank-Bank yang Beroperasional di Banda Aceh). Jurnal Akuntansi Pascasarjana Universitas Syiah Kuala, $2(1): 127-141$.

Nafarin. (2017). Penganggaran Perusahaan. Jakarta:Salemba Empat.

Natalia, D., P. 2010. Pengaruh Komitmen Organisasional dan Peran Manajer Pengelolaan Keuangan Daerah Terhadap Kinerja Manajerial Satuan Kerja Perangkat Daerah. Skripsi. Universitas Diponegoro.

Neng, S. (2015). Pengaruh Kejelasan Sasaran Anggaran, Kualitas Sumber daya Manusia dan Komitmen Organisasi Terhadap Kinerja Pengelolaan Keuangan Daerah Di Lingkungan Pemerintah Kota Bandung. Jurnal. 19(8). ISSN 6664.3821.

Nofisa, V. 2014. Pengaruh Akuntabilitas Publik, Partisipasi Penyusunan Anggaran Dan Kejelasan Sasaran Anggaran Terhadap Kinerja Manajerial SKPD (Studi Empiris pada Satuan Kerja Perangkat Daerah di Kabupaten Sijunjung).

Parulin. (2017). Dasar-Dasar Akuntansi Manajemen. Yogyakarta: UPPAMP YKPN.

Prawirosentono, (2013). Sistem Pengendalian Manajemen. Edisi 11. Jakarta: Salemba Empat.

Rahma. 2019. Pengaruh Pelatihan dan Tingkat Pendidikan Terhadap Kinerja Pegawai pada Dinas Kesehatan Pesisir Selatan.

Rifqi S., H. (2019). The Influence of Budget Participation, Budget Goals Clarity and Internal Control Systems Implementation on Local Government Performance. 2 (2).

Rizka W, dkk. (2014). Pengaruh Kejelasan Sasaran Anggaran, Desentralisasi Dan Akuntabilitas Publik Terhadap Kinerja Manajerial Satuan Kerja Perangkat Daerah (Studi Kasus Pada SKPD Kota Pekanbaru). Jurnal. 19(8). ISSN 6664.3821.

Rusdianto. (2013). Akuntansi Sektor Publik Suatu Pengantar. Jakarta: Erlangga.

Rona, E .2017. Pengaruh Kejelasan Sasaran Anggaran, Akuntabilitas Publik, Dan Sistem Pelaporan Terhadap Kinerja Manajerial (Studi Empiris Pada SKPD Kabupaten Rokan Hulu).

Samuel. (2014). Cost Accounting: A Managerial Emphaisis. Eleventh Edition. New Jersey: Pretice Hall.

Sugiyono. (2014). Metode Penelitian Pendidikan Pendekatan Kuantitatif, Kualitatif. $R \& B$. Bandung: Alfabeta.

Suhartono. (2016). Pokok-Pokok Akuntansi Lanjutan Pemerintah. Jakarta: Salemba Empat.

Suharyadi \& Purwanto. (2017). Statistika untuk Ekonomi dan Keuangan Modern. Jakarta: Salemba Empat.

Supomo \& Indriantoro. (2011). Manajemen Sumber Daya Manusia Untuk Bisnis Yang Kompetitif. Yogyakarta: Gadjah Mada Universitas.

Sri P. (2018). Effect of Clarity of Budget Objectives, Accounting Control, Reporting Systems, Compliance with Regulation on Performance Accountability of Government Agencies. Advances in Social Science, Education and Humanities Research, 292.

Simamora, Henry. (2011). Akuntansi Manajemen. Jakarta: Salemba Empat.

Sitepu. (2014). Metodologi Penelitian. Bandung: Fokus Media.

Teguh, M. (2019). Pengaruh Latar Belakang Pendidikan, Pengalaman, Pelatihan Dan Hubungan Antar Karyawan Terhadap Kinerja Mantri Pada Pt Bank Rakyat Indonesia (Persero) Tbk Cabang Samudera Banjarmasin. At-Tadbir: Jurnal Ilmiah Manajemen 3 (1), 11-18.

Tresna. (2015). Manajemen Pendidikan Indonesia. Jakarta: Bumi Aksara. 
Undang-Undang Nomor 20 Tahun 2003, Tentang Sistem Pendidikan Nasional.

Ujiyantho, A. (2007). Asimetri Informasi dan Manajemen Laba suatu Tinjauan dalam Hubungan Keagenan. Jurnal Riset Akuntansi Indonesia.

Yuhelmi, 2019. Pengaruh Kejelasan Sasaran Anggaran dan Akuntansi Pertanggungjawaban Terhadap Kinerja Manajerial di Inspektorat Kota Padang.

Wilson, J., O. \& John B. C. (2012). Controllership: The Work of Managerial Accountant. 3rd Edition. Long Angeles: John Wisey and Sons, Inc. Dialihbahasakan oleh Tjintjin Fenix Tjendra. 1997. Controllership: Tugas Akuntan Manajemen: Edisi Ketiga. Jakarta: Erlangga. 